\title{
sciendo
}

\section{Rising tensions along the agri-food value chains during the COVID-19 crisis: evidence based on Google Trends Data}

\author{
Marius CONSTANTIN \\ Bucharest University of Economic Studies, Bucharest, Romania \\ marius.constantin@eam.ase.ro \\ Simona Roxana PĂTĂRLĂGEANU \\ Bucharest University of Economic Studies, Bucharest, Romania \\ rpatarlageanu@eam.ase.ro \\ Mihai DINU \\ Bucharest University of Economic Studies, Bucharest, Romania \\ mihai.dinu@eam.ase.ro \\ Raluca IGNAT \\ Bucharest University of Economic Studies, Bucharest, Romania \\ raluca.ignat@ase.ro
}

\begin{abstract}
The global socio-economic and sanitary crisis caused by the COVID-19 pandemic has generated many different effects on the links of the global agri-food value chains regarding the production and consumption behaviors of agri-food products. Depending on the link, these effects can be positive, negative, or even a mix of both. However, all these sudden changes, beneficial or not, they result in deepening the economic tensions existing along the agri-food value chains. In this context, the aim of this research was to explore the rising tensions along the Romanian agri-food value chains during the different stages of the COVID-19 crisis in Romania, while bringing the HoReCa industry in the spotlight of this study, and, more specifically, the food service component. This paper brings contribution to the literature concerning the implications of the COVID-19 pandemic at the level of the agri-food value chains based on a statistical analysis carried out with the data available from two open access sources: Google Trends and the Romanian National Institute of Statistics. A short bibliometric analysis was also elaborated on the papers tackling the topic of the rising tensions along the agri-food value chains during the pandemic. Research results show that the Romanian HoReCa industry has been subject to various challenges emerged from the need to limit the spread of the COVID-19 disease. This has generated a lot of concern-not only from the food security perspective, but also from the perspective of the entrepreneurs active in the agri-food value chains. Food-ordering companies with homedelivery have been of high interest during the COVID-19 pandemic, as they connect two major links in the food chain: restaurants and consumers. While consumers have become more dependent than ever on digital solutions to purchase food, a lot of pressure is put on indoor restaurants.
\end{abstract}

Keywords: agri-food value chains; food sector; HoReCa industry; Google Trends; Romania.

\section{Introduction}

At the beginning of 2021, countries all around the world are still facing major issues caused by the COVID-19 pandemic. Ever since it was declared a pandemic in March 2020 (World Health Organization, 2020), more than 100 million people were reported to have been infected globally, more than 2 million people died and studies focused on forecasting indicate that increasing trends 
are observed in many countries and regions, arguing for decision makers to take immediate actions in the light of preventing the rapid spread of this highly contagious disease (Bhangu, Sandhu and Sapra, 2021; Wang et al., 2021; Nikolopoulos et al., 2021).

During such a global climate characterized by the sanitary crisis and socio-economic instability (Gómez and Favorito, 2020), the links of the food value chains are facing many challenges in terms of applying the precautionary measures meant to limit the spread of COVID-19 disease (Shahbaz et al., 2020). Such measures could represent one of the reasons why entrepreneurial intention decreased in the food industry, even in wealthy regions (Ignat and Constantin, 2020a). Affected by the state of uncertainty and by the new working conditions that must be respected by each link of the food value chains, emerging entrepreneurs are negatively impacted by the pandemic and are feeling discouraged to launch new business in the market. Consequently, additional tension along the agri-food chains is generated by the uncertainty of maintaining food security. Consumers can change behaviors and rapidly increase the demand of agri-food products, leaving no time for the existing links to prepare according to the demand.

Regarding the actions of the players active in the agri-food industry from the Romanian private sector, the following short-term economic consequences of the COVID-19 crisis were observed: (i) the turnover value index of wholesalers of agricultural raw materials and live animals reached new peaks at the beginning of the COVID-19 pandemic; (ii) meat and poultry meat products registered the greatest increases of the national production price indices among all agrifood product categories; (iii) during the initial lockdown (March - April 2020), no major prices increase or decrease were observed concerning the agri-food products - nationally (referring to the average price),compared to the period before the COVID-19 outbreak (Ignat and Constantin, 2020b). In some extreme cases, Suceava County for example, the COVID-19 pandemic generated significant changes in regard to consumers purchasing behavior of fresh vegetables (Butu et al., 2020). Before enforcing the state of emergency on 16 March, 2020 (Hâncean, Perc and Lerner, 2020), only few fresh vegetables consumers chose to purchase online such products. However, according to Butu et al. (2020), the option to purchase online became more attractive and was a real solution for $60 \%$ more consumers of fresh vegetables during the COVID-19 lockdown.

Since ensuring high degrees of food security is one of the imperatives for any fully operational agricultural system (Istudor et al., 2019; Drăgoi et al., 2018), consolidating resilience in food system is the key to successfully build not only an operational agricultural system, but a sustainable one at the same time. Consolidating resilience in food systems is about ensuring capacities. Insurances, automation, connectivity, diversification, digital platforms, market integration, innovative transportation solutions - they are all puzzle pieces needed for building a highly resilient agricultural system, with a high degree of food security (Béné, 2020). Inclusion, better access to information, knowledge transfer and stronger cooperation are also ingredients for a sustainable and resilient agricultural system. Powerful bonds and honest cooperation also contribute to mitigating tensions along the agri-food value chains (Berti and Mulligan, 2016).

This paper complements the existing literature concerning agri-food value chains during times of crisis and brings its unique contribution. This research expands the field of knowledge by providing insight on the emergence of additional pressure on the links of the Romanian agri-food value chains during the COVID-19 crisis.

The objective of this research was to explore the rising tensions along the Romanian agrifood value chains during the COVID-19 socio-economic and sanitary crisis in Romania. The food service industry was brought in the spotlight of this research. Additionally, tensions concerning the HoReCa industry were also approached according to various stages of the COVID-19 pandemic.

DOI: 10.2478/picbe-2021-0029, pp. 302-316, ISSN 2558-9652 |

Proceedings of the $15^{\text {th }}$ International Conference on Business Excellence 2021 
This paper has a traditional format. In the first part of the paper, a literature review was carried out, consisting of a short bibliometric analysis on the scientific papers indexed in the Web of Science database, papers written on the topic of the existing pressure along the links of the agrifood value chains during the COVID-19 pandemic. In addition, the literature review section contains two subchapters: one concerning the implications of the COVID-19 pandemic at the level of the agri-food value chains, while the other is focused on the HoReCa industry and on the food service component. After the literature review chapter, the research methodology is explained, followed by the section dedicated to results and discussions. Finally, the conclusions of this research are pointed out, as well as the limitations. Further research directions are also suggested.

\section{Literature review}

Before the standard approach on the literature concerning the agri-food value chains and the implications of the COVID-19 pandemic in the generation of tension or pressure at the level of the chain links, a brief bibliometric analysis was carried out. The purpose of this approach was to identify initial correlations between the words included in the title and abstract of the publications indexed in the Web of Science database relevant for this research.

The Web of Science database was queried according to the following specification: TOPIC: (pressure) AND TOPIC: (food)AND TOPIC: (supply) AND TOPIC: (COVID-19)Timespan: All years. Indexes: SCI-EXPANDED, SSCI, A \& HCI, CPCI-S, CPCI-SSH, BKCI-S, BKCI-SSH, ESCI, CCR-EXPANDED, IC. There were 12 publications identified on 23 January 2021, based on the previously mentioned query. Linking these four structures together ("pressure", "food", "supply" and "COVID-19") represented the premises of identifying scientific papers tackling the topic of the rising tensions along the agri-food value chains during the COVID-19 crisis. The identified documents were processed in VOS viewer 1.16.16 and Figure 1 was elaborated.

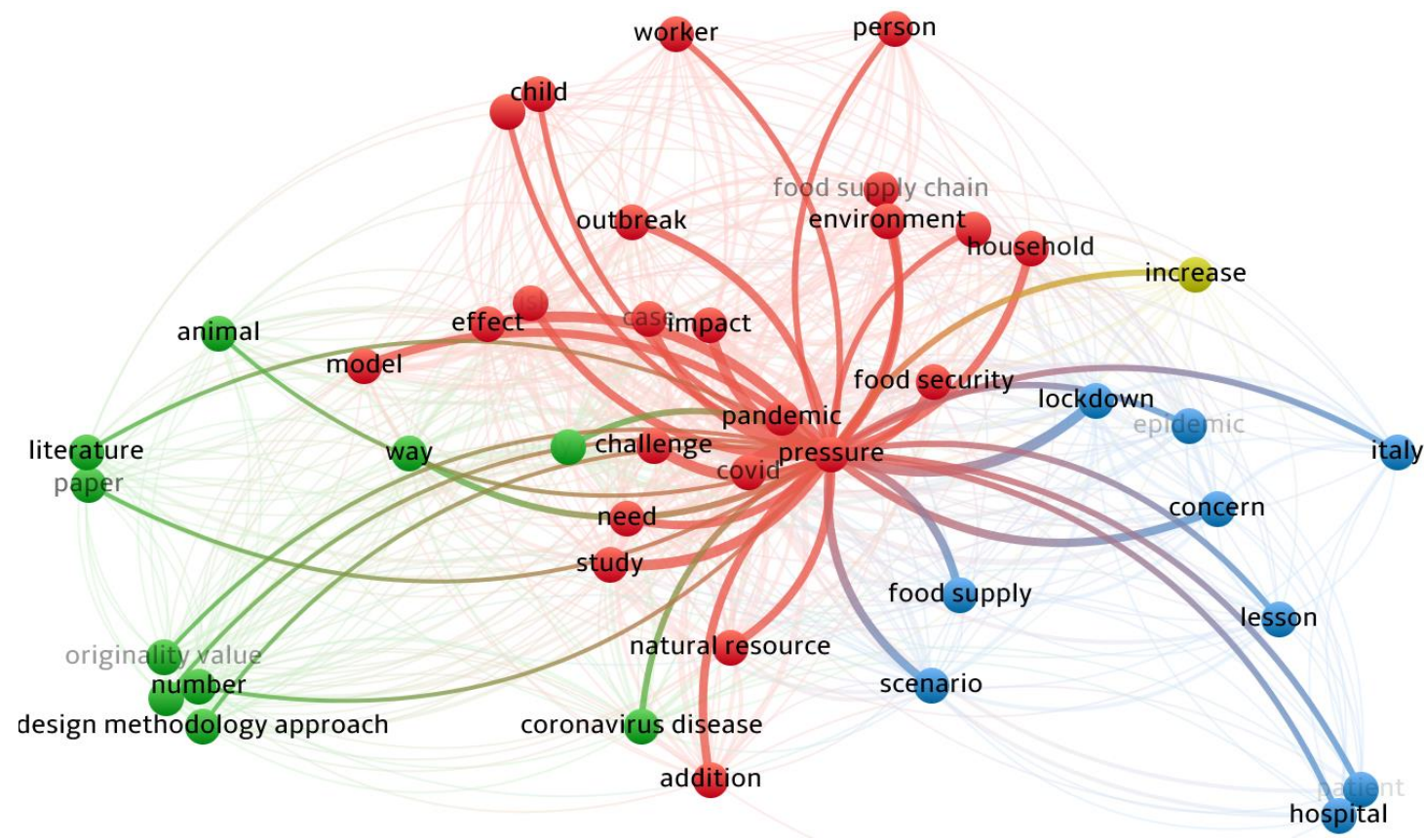

Figure 1. The correlation between the word "pressure" with the rest of the words present in the title and abstract of the publications approaching the researched topic

Source: Authors' processing and representation in VOS viewer 1.16.16, based on Web of Science metadata.

DOI: 10.2478/picbe-2021-0029, pp. 302-316, ISSN 2558-9652 |

Proceedings of the $15^{\text {th }}$ International Conference on Business Excellence 2021 
The tension along the agri-food value chains during the COVID-19 crisis is a topic tied to food security issues, as illustrated in Figure 1. Since they are all a matter of "natural resource" (red cluster) management, the "environment"-aspect (red cluster) was also approached in relation with these topics and with the impact of the "coronavirus disease" (green cluster) on the "food supply chain" (red cluster). This "food supply" (blue cluster) "challenge" (red cluster) has had a steady "increase" (yellow cluster) after the COVID-19 "outbreak" (red cluster).

\section{The implications of the COVID-19 pandemic at the level of the agri-food value chains}

The effects of the emergence and expansion of COVID-19 have been felt both globally and nationally. In a first phase, they led to the appearance of issues in the health systems and to a sudden decrease of the economic activities worldwide. Since early 2020, in order to reduce the spread of the disease, each state has taken unprecedented measures. We can mention the restriction or suspension of the activity of certain sectors such as tourism, organization of events, HoReCa and traditional trade. However, during this period there were also development opportunities in areas such as video communications, online commerce and, of course, the activity of courier companies.

In the context of the lack of information on how the pandemic will evolve, starting with the months of February-March of 2020, a large part of the population felt insecure about income. At the same time, the restriction on freedom of movement and social interactions, the possibility of problems in the supply chains have led to an increase in demand for food. Thus, the tendency among the population to stock up on food stocks for a longer period was observed and there was even a peak of consumption, after which things were approximately adjusted. Of course, the increase in demand has led to price increases for certain products, especially health and food products. In some countries around the world, stocks for these products have been depleted in some supermarket chains.

Lack of food can lead to public disturbances, so special attention must be paid to agri-food chains, referring to the production, processing and distribution of food to the final consumer. One of our proposals for mitigating future risks would be to practice short food supply chain as widely as possible, which means selling from the farmer to the consumer by involving as few intermediaries as possible. At the same time, another proposal refers to a closer cooperation between the biggest retailers and the local producers, insofar as the producer would have assured the sales market, with the uniformity and quality conditions desired by the clients, and the traders obtain the products necessary for the sale. Another measure that could be implemented at the level of each country is to create and maintain reserve stocks, so that there is no need to impose measures to restrict trade and mobility of goods in crisis situations, such as the COVID-19 pandemic.

\section{The HoReCa industry and the food service component}

At this time, no one knows how long the economic and health crisis caused by the COVID-19 pandemic will last. It could be the end of this year when a decrease in the intensity of the virus might be observed in the situation in which the vaccination process intensifies globally.

The HoReCa sector is one of the most affected sectors by this pandemic, taking into account that it has been targeted by restrictions imposed by the administrations world-wide, both during and after the state of emergency. Tourism has also been severely affected due to travel restrictions, both land and air. In this context, accommodation structures, food structures and travel agencies are among the most affected in the national economy. However, the situation has been different in the case of activities specific to the delivery of food at home or at work. 
According to official statistics, provided by the National Institute of Statistics (2021), the total number of overnight stays, for Romanians and foreigners, in tourist reception facilities has halved in January-September 2020, compared to the same period of 2019, and overnight stays of foreign tourists have decreased by about $80 \%$. Of course, the decrease in tourist traffic had repercussions on the activity of companies, respectively on turnover. According to the National Agency for Fiscal Administration on turnover for the first half of 2020, compared to the first half of 2019, it is found that in terms of accommodation structures, there was a reduction in turnover by $36.8 \%$, in terms of food structures, a reduction in turnover was registered by $33.5 \%$, and with regard to travel agencies, a reduction in turnover by $60,5 \%$ was registered (Government of Romania, 2020).

During this period it is very important to ensure access to food for the population. Therefore, the agri-food chain and the medical system represent strategic sectors in each country. High importance must also be given to ensuring safety and health at work, as a determining factor in the management of the pandemic and for the possibility of reopening to a lower or higher capacity of HoReCa services. However, even during this period, many restaurants have adapted by offering home-delivery services, using their own means of transport, but most often using the services of other companies dealing with food ordering and home delivery.

A possible solution would be to support small farmers in order to direct some products to the market, of course in compliance with all rules of hygiene and food safety. Local farmers and fishermen can deliver fresh food directly to final consumers or to HoReCa.

\section{Methodology}

Based on data availability at the moment of elaborating this paper (the beginning of February 2021), the following indicators were considered relevant for this research and selected to be included in the statistical analysis: (i) the Google search interest score; (ii) the number of tourists (Romanian and foreigners) accommodated in tourist reception units in Romania; (iii) the share of active enterprises in HoReCa industry from the total active enterprises at country level in Romania; (iv) the share of active enterprises in HoReCa industry from the total active enterprises nationally in Romania. Statistical data used in this paper can be viewed or downloaded in open access regime from the Google Trends platform in the case of indicator (i) and from the TEMPO Online platform in the case of indicators (ii)-(iv).

Highly used to analyse interests across various fields since May 11 2006, Google Trends is an online tracking system of web-based hit-search volumes designed to help exploring internet activities (Jun, Yoo and Choi, 2018). The portal determines the proportion of searches for userspecified terms among all searches performed using Google. Based on this, the system generates an interest score which does not represent absolute search volume numbers based on searches, because data is normalized by Google and presented on a scale from 0 to 100 . Each point is divided by the highest one, conventionally set at 100. However, spikes in a particular topic do not specifically represent that the topic is "winning" (Google Inc., 2021), but that many users perform internet searches about that particular topic for some reasons. Studies have demonstrated that Google Trends and search engine data act as a valuable asset for carrying out socio-economic research (Choi and Varial, 2012; Vosen and Schmidt, 2011; Batool et al., 2020).

Additional methodological details regarding the rest of the indicators: the number of tourists (Romanian and foreigners) accommodated in tourist reception units in Romania are considered people who travel outside their locality, for a period of less than 12 months, spending at least one night in a tourist reception units and the main purpose of the journey is other than that 
of carrying remunerated activities in the visited place (NIS indicator code: TUR104F. Latest data available: July 2020, accessed on January 22, 2021). An active enterprise is considered any entity that is economically active during the observation period - it produces goods or provides services (NIS indicator code: INT101O. Latest data available: Year 2019, accessed on January 22, 2021).Data concerning the financial results of the companies that carry out food service activities are crucial for this analysis, yet not available. Publishing new financial official data characterized by the influence of the COVID-19 pandemic will allow this study to be extended. Considering that the HoReCa industry was forced to change its managerial processes and even to limit them during specific periods, the financial results of the active companies in this industry are expected to significantly differ from any previous results, since the modern world faced a pandemic of this magnitude for the first time.

\section{Results and discussions}

In order to explore the rising tensions along the agri-food value chains during the COVID-19 crisis in the case of the Romanian HoReCa industry and its food service component, the research started with the analysis of the evolution concerning the interest for the HoReCa industry in relation with the interest for food. Based on Google Trends statistical data, Figure 2 was elaborated with the aim of observing similarities and differences between the evolution of the interest score of the following keywords:"HoReCa" and "mâncare" (Romanian word, translates to "food" in English).

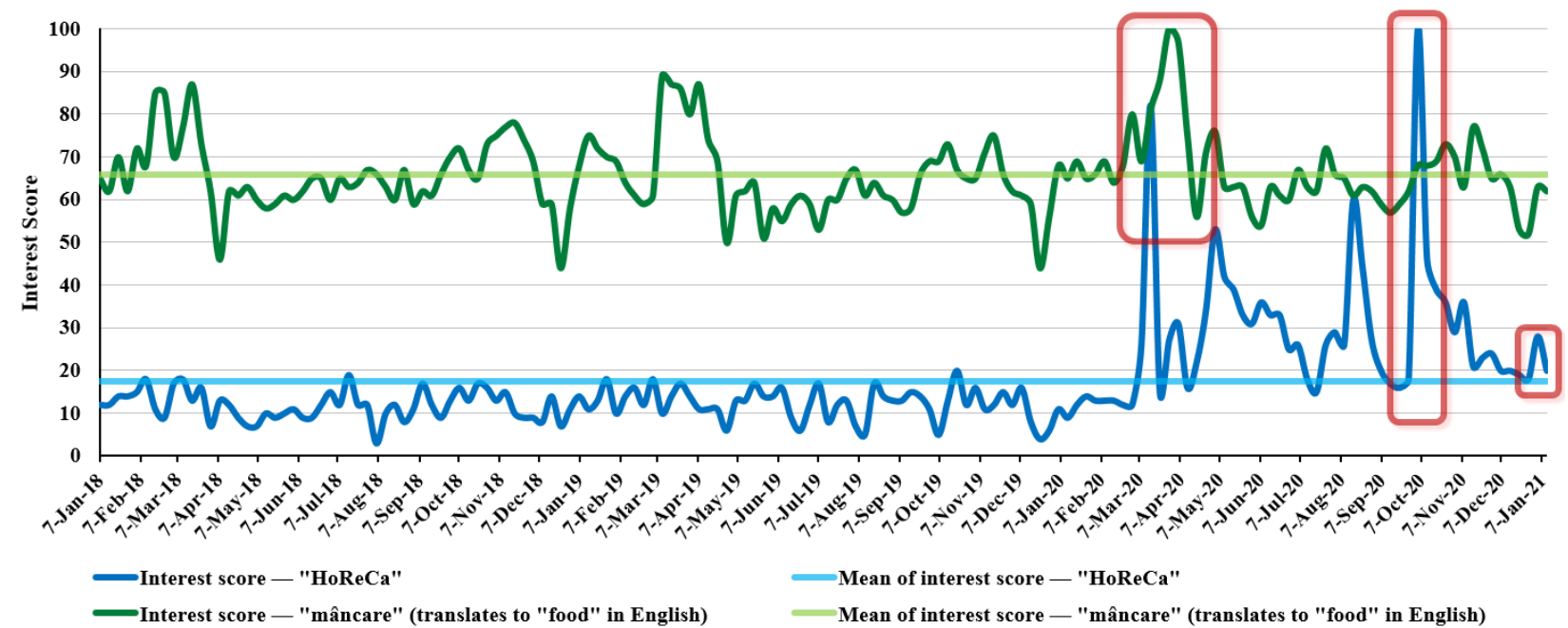

Figure 2. The interest score evolution of the following Google web researches:

"HoReCa" and "mâncare" (Romanian word, translates to "food" in English)

Source: Authors' visualrepresentation of Google Inc.'s raw data, 2021, https://trends.google.com/trends/explore?date=today\%205-y\&geo=RO\&q=HoReCa.

During the analyzed period, January 2018 - January 2021, the average of the interest score concerning food was 3.76 times greater than the one referring to the HoReCa industry, signaling that food was a topic of constant interest for Romanians (mean interest score being 65.94, while the standard deviation was only 8.94). On the contrary, the standard deviation of the interest score corresponding to the HoReCa industry represented $71.95 \%$ of the mean - signaling sudden interest increase or decrease bursts, as one can notice from Figure 2. This proves rising tensions along the links of the food service chain, part of the HoReCa industry, especially during times of crisis. Not only that, but this result also puts the resilience of the Romanian HoReCa industry at doubt - Why 
would the interest for this particular industry burst over such a short period of time if there are no reasons to worry about, just like in the case of the Google web searches regarding food. In the case of the latter, the interest score peaked during the beginning of the COVID-19 crisis, on 29 March, 2020 - yet the interest score reached similar high values in the past: 89 on 10 March, 2019. On the other hand, in the case of the HoReCa industry, the average of the interest score during the January 2018 - 8 March 2020 period was 12.23. This average interest score has more than doubled (reached 31.20) during the period specific to the COVID-19 pandemic: 15 March 2020 - January 2021.

Taking a deeper look at the March 2020 - January 2021 period, one can notice an initial burst of the interest score concerning the Romanian HoReCa industry on 15 March 2020, when it reached its second biggest value: 89 . One possible explanation is that the national lockdown caused a lot of doubts in regard to the resilience of the Romanian HoReCa industry in the face of the unprecedented COVID-19 sanitary crisis. After this initial burst, the interest decreased and reached new significant values on 3 May, 2020 (53) and on 16 August, 2020 (60). The increase from May could be justified by the fact the Romanian Prime Minister at that time made public statements at the beginning of May regarding the Government's plan to allow hotels to function, yet not indoor restaurants (DIGI24, 2020). This caused the intensification of the tension felt along the links of the Romanian food system. The increase from August could be explained by Romanian HoReCa industry's protests in reaction to the strict governmental measures designed to limit the spread of the COVID-19 disease. (Forbes România, 2020). On October 4, 2020, the interest score corresponding to the HoReCa industry reached the maximum value (100), probably because of the more protests taking place in Piaţa Victoriei, near Victoria Palace, which houses the Prime Minister of Romania and his cabinet (RFI România, 2020). After October 2020, the interest score dropped, but it is possible to reach higher values again at the end of January 2021, considering that the Romania's new Prime Minister, Florin Cîţu, declared that restaurants might resume their activities, but to a limited extent, starting from 25 January 2021 (Ziarul Bursa, 2021).

It is well known that the HoReCa industry contributes to building a more sustainable local economy and that an increase of the revenues generated by tourism-related industries can be successful in overcoming economic stagnation (Balaguer and Cantavella-Jorda, 2002; Tang and Jang, 2009; Pătărlăgeanu, Dinu and Constantin, 2020; Andrei and Drăgoi, 2020). Stimulating tourism also brings many economic benefits to the links of agri-food value chains (Konishi, 2019; Schubert and Schamel, 2020). In some cases, tourism even helped economies to significantly reduce the overall negative economic impact of recession (Mikulic, Decek and Hrustek, 2017). However, tourism is now affected by an enemy that proved to be very challenging to stand up to the novel coronavirus disease. Even though tourism contributed to reviving local economies during periods by recession, now the companies active in the tourism sector are facing economic problems of a magnitude capable to diminish the progress made in recent years, including those specific to the sustainable development goals (Gössling, Scott and Hall, 2020). In this context, Figure 3 was elaborated with the purpose of studying the evolution of the number of tourists, Romanian and foreigners, accommodated in tourist reception units in Romania in relation with the interest expressed for the HoReCa industry based on the evolution of the Google web searches performed in Romania corresponding to the "HoReCa" keyword on Google's search engine. 


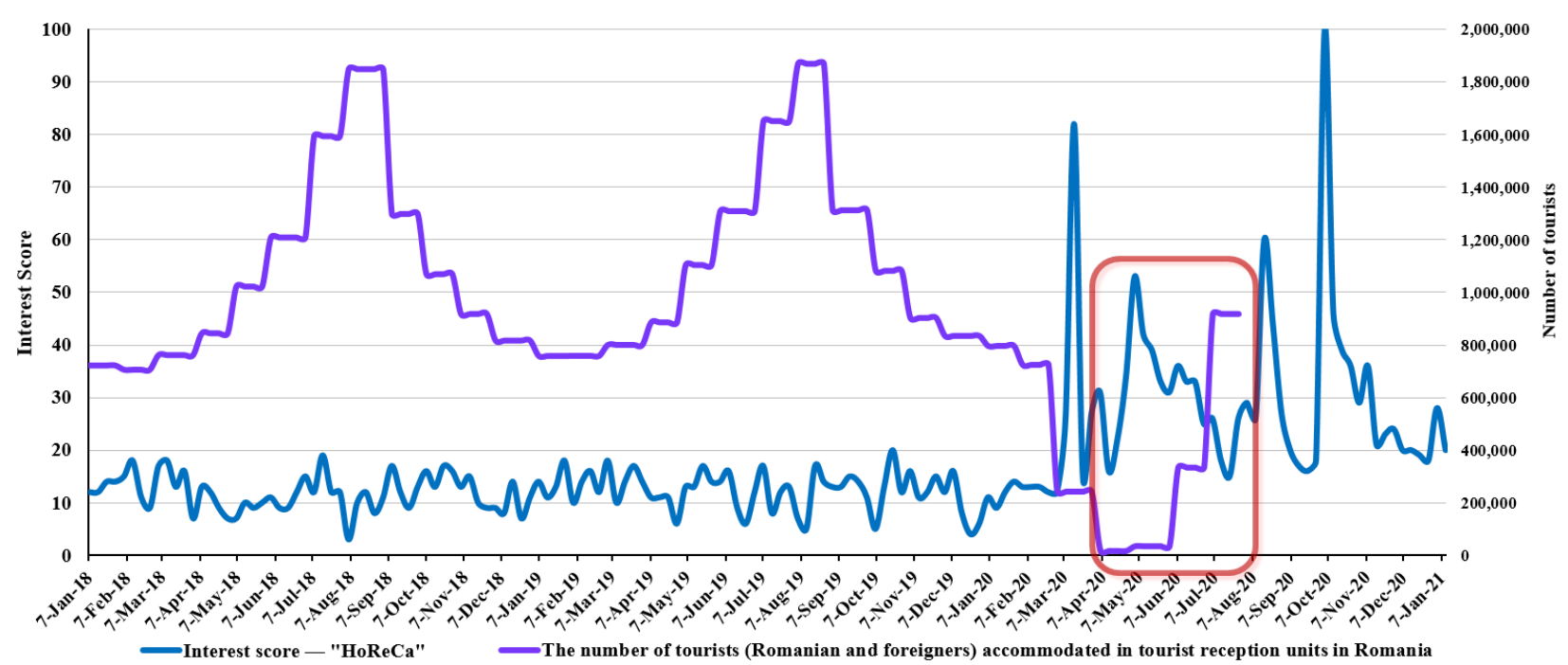

PICBE |

Figure 3. The interest score evolution of the "HoReCa" Google web research" in relation with the number of tourists (Romanian and foreigners) accommodated in tourist reception units in Romania Source: Authors' processing and representation of data, Google Inc. and the National Institute of Statistics, 2021.

During the first two years of analysis, 2018 and 2019, the trend concerning the number of tourists accommodated in tourist reception units in Romania follows a normal distribution, which is also the case of the interest score of the "HoReCa" industry. The latter reached a minimum value of 3 on 5 August, 2018 - probably caused by the fact that a lot of Romanians were actually travelling in August, peak travel month: 5,750,352 tourists in 2018 and 1,545,257 in 2019. However, this has changed since March 2020. Considering the March - July period, a decrease was registered in 2020 in regards to the number of tourists, since there were 4,205,095 less people accommodated in tourist reception units (73.1\% decrease, 2020 reported to 2019). The biggest decrease was tracked in April 2020 (98.1\% decrease, 2020 reported to 2019), since Romania accommodated 868,967 less tourists, while July was the least negatively affected month (44.42\% decrease, 2020 reported to 2019, representing a loss of 733,557 tourists). Data after July 2020 was not available at the moment of elaborating this research. As tourism activity dropped in March 2020, the interest for the HoReCa industry registered a boom in March (interest score of 82), followed by a decrease in April (interest score of 16) and by a small increase in May (interest score of 53 on May 3, 2020), with a peak on October 4, 2020 (interest score of 100). After peaking in October 2020, the interest for the HoReCa industry has decreased, but then began rising again in January 2021, on the premises of restaurants being able to accept customers indoors starting from 25 January, 2021. This analysis proves that the restrictions imposed by limiting the spread of the COVID-19 disease ignited the intention for travelling, dining at restaurants and other similar leisure activities that were free to carry out before the COVID-19 pandemic. Even though the restrictions have changed during the evolution of the pandemic, they have also kept the interest alive for carrying out activities specific to travelling, dining, food tourism and others.

In this context, it is important to study the impact of the COVID-19 pandemic at the level of the existing active entrepreneurs in the HoReCa industry in Romania. Since the tourism-related attractivity is different regionally based on many factors (Dinu et al., 2020), Figure 4 was elaborated with the purpose of studying the county-level impact of the HoReCa industry on the local economy, while Figure 5 was designed with the purpose of studying the most vulnerable counties to the COVID-19 restrictions, based on the distribution of HoReCa companies, nationally. 


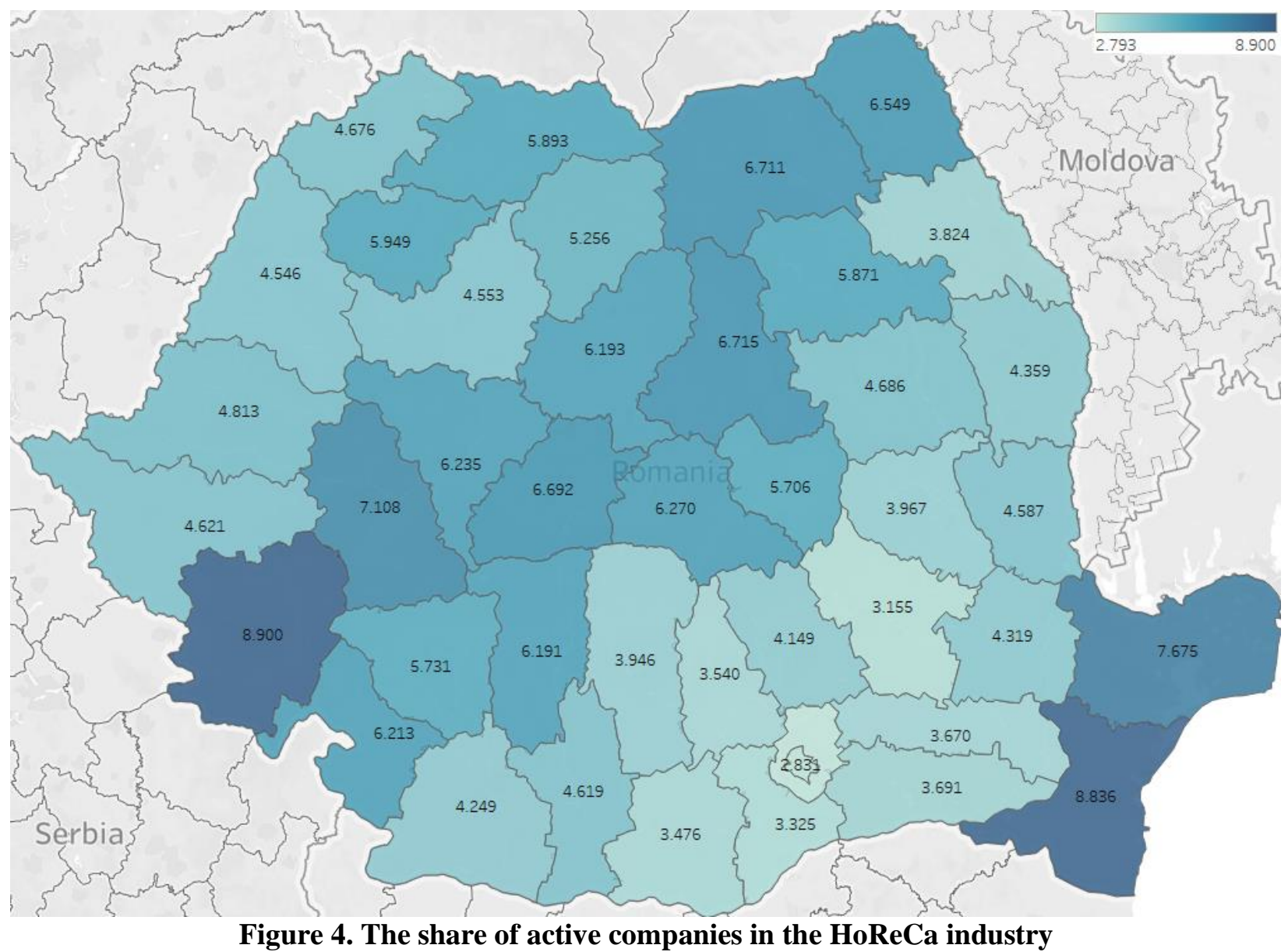

PICBE |

from the total active companies at county level in Romania, year of reference: 2019

Source: Authors' processing and representation in Tableau, data source: the National Institute of Statistics, 2021.

Judging from the perspective of the share of active enterprises in HoReCa from the total active enterprises at county level, the most endangered local economies in the face of the COVID-19 pandemic are the following: Caraş-Severin County and Constanţa County $(\approx 8.87 \%$ of the total active enterpises in these counties are part of the HoReCa industry), Tulcea County and Hunedoara County County $(\approx 7.39 \%$ of the total active enterpises in these counties are part of the HoReCa industry), Harghita County, Suceava County, Sibiu County, Botoşani County, Braşov County, Alba County, Mehedinţi County, Mureş County and Vâlcea County $(\approx 6.42 \%$ of the total active enterprises in these counties are part of the HoReCa industry). In Romania's capital, Bucharest, the share of active companies in the HoReCa industry from the total active companies registered only a percentage of $2.83 \%$. The national average of this share was $5.17 \%$ and standard deviation was $1.49 \%$ ( $\mathrm{N}=42$ Romanian counties). This statistics highlight of all the active entrepreneurs, $5.17 \%$ of them were carrying out activities in the HoReCa industry in 2019 in Romania, at the level of counties. Since all these entrepreneurs were probably exposed to the negative effects of the COVID-19 pandemic, 5.17\% represents the percentage of the endangered economic group of companies at local level, on average. 


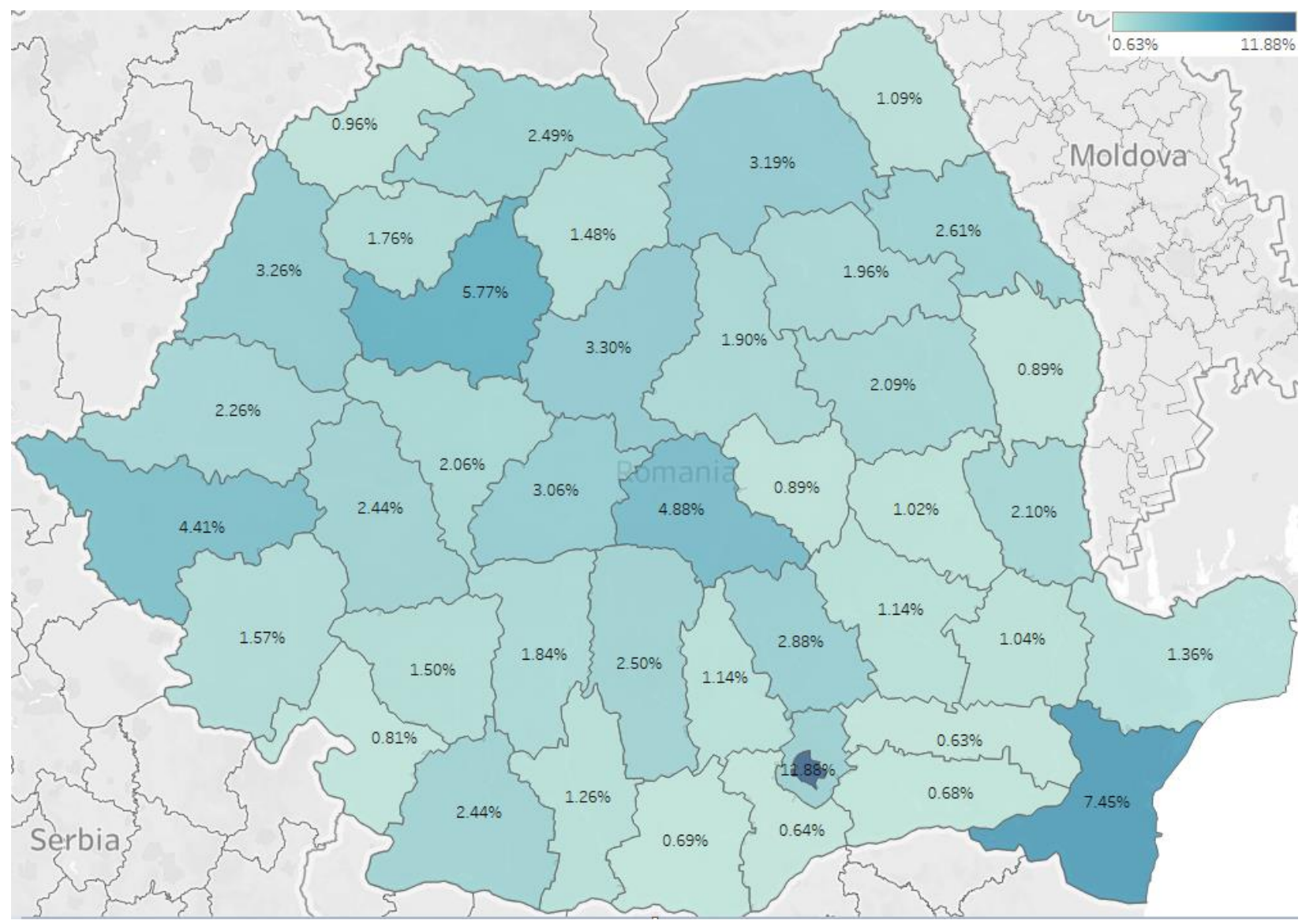

PICBE |

Figure 5. The share of active companies in the HoReCa industry

from the total active companies at country level in Romania,year of reference: 2019

Source: Authors' processing and representation in Tableau, data source: the National Institute of Statistics, 2021.

Looking at the most vulnerable Romanian counties to the COVID-19 pandemic restrictions based on the national distribution of HoReCa companies, the capital was the most affected. The reason for this is that $11.88 \%$ of all the Romanian HoReCa companies are active in Bucharest. Next in this top are the following counties: Constanţa County $(7.45 \%)$, Cluj County $(5.77 \%)$, Braşov County (4.88\%), Timiş County (4.41\%), Mureș County (3.30\%), Bihor County (3.26\%), Suceava County (3.19\%) and Sibiu County (3.06\%). Ialomiţa County, Giurgiu County, Călăraşi County, Teleorman County, Mehedinţi County, Vaslui County, Covasna County and Satu Mare County are 8 counties that sum $6.2 \%$ of the total companies active in the Romanian HoReCa industry. Although they may not represent major contributors to the national HoReCa economy, this industry and its food service component still gathers a considerable share of the local economy, judging from the perspective of the number of active companies.

The food service component of the HoReCa industry deserves additional attention, especially since the analysis was focused on the HoReCa industry as a whole up until this point. In accordance with the research methodology, this paper follows a normal flow and includes an analysis of the main food ordering and home delivery companies active in Romania, based on Google Trends statistical data. The web searches included in this analysis are detailed in Table 1. 
Table 1. Selected Google web search for the Google Trends analysis of the main food ordering and home delivery companies active in Romania. Short description of the companies.

\begin{tabular}{|c|c|c|}
\hline Google Web Search & Short Company Description and Discussion & $\begin{array}{l}\text { Launch Date } \\
\text { in Romania }\end{array}$ \\
\hline "Glovo" & $\begin{array}{l}\text { Spanish start-up born in Barcelona in } 2015 \text {. Acts as an } \\
\text { on-demand courier service through its mobile app. } \\
\text { Delivering food to clients during the COVID-19 } \\
\text { pandemic was one of the key factors that contributed to } \\
\text { limiting the spread of the disease, while demonstrating } \\
\text { the resilience of the business model during times of } \\
\text { socio-economic and sanitary crisis (Polkowska, 2020). }\end{array}$ & 2018 \\
\hline "Takeaway" & $\begin{array}{l}\text { Anglo-Dutch company specialized in online food } \\
\text { ordering and home delivery, acting as an intermediary } \\
\text { online portal or application (in case of mobile devices) } \\
\text { between customers and the restaurants. Kerigan (2020) } \\
\text { considers that if the COVID-19 crisis is not being } \\
\text { properly managed, this situation will continue to favor } \\
\text { digital business models like Takeaway, mainly because } \\
\text { of the delivery services. Such business models have the } \\
\text { upper hand over physical restaurants and similar venues } \\
\text { dedicated to the food service industry. }\end{array}$ & 2018 \\
\hline "Uber Eats" & $\begin{array}{l}\text { American online food ordering and delivery platform. } \\
\text { Raj, Sundararajan and You (2020) analyze the critical } \\
\text { role Uber Eats has played in consolidating economic } \\
\text { resilience during the COVID-19 pandemic, while still } \\
\text { providing new managerial insight in regard to how food } \\
\text { supply-side and demand-side factors shape business } \\
\text { performance through a digital platform. }\end{array}$ & $\begin{array}{l}2018^{*} \\
{ }^{*} \text { Closed its } \\
\text { operations } \\
\text { in Romania } \\
\text { in June, } \\
2020 .\end{array}$ \\
\hline "Food Panda" & $\begin{array}{l}\text { Berlin-based company that designed a mobile food } \\
\text { delivery marketplace with an integrated delivery } \\
\text { component. Chang and Meyerhoefer (2020) argue that } \\
\text { companies like Food Panda proved to be close to } \\
\text { consumers during the pandemic. The same study shows } \\
\text { that consumers who purchased food through such } \\
\text { platforms for the first time during the lockdown, will } \\
\text { continue to purchase food online in the future. }\end{array}$ & 2013 \\
\hline
\end{tabular}

Source: Authors' selection of Google web searches, according to the objectives of this research.

In accordance with the research methodology, the same statistical processing was carried out in regard to the Google web searches explained in Table 1. The analysis of interest for the food home delivery companies detailed in Table 1 is valuable in the context of this research, because it contributes to a better understanding of an another facet of the Romanian food service facing the COVID-19 pandemic. Consequently, Figure 6 was elaborated with the purpose of observing the evolution of the Google web searches performed in Romania based on the keywords corresponding to the main food ordering and home delivery active companies from Romania. 


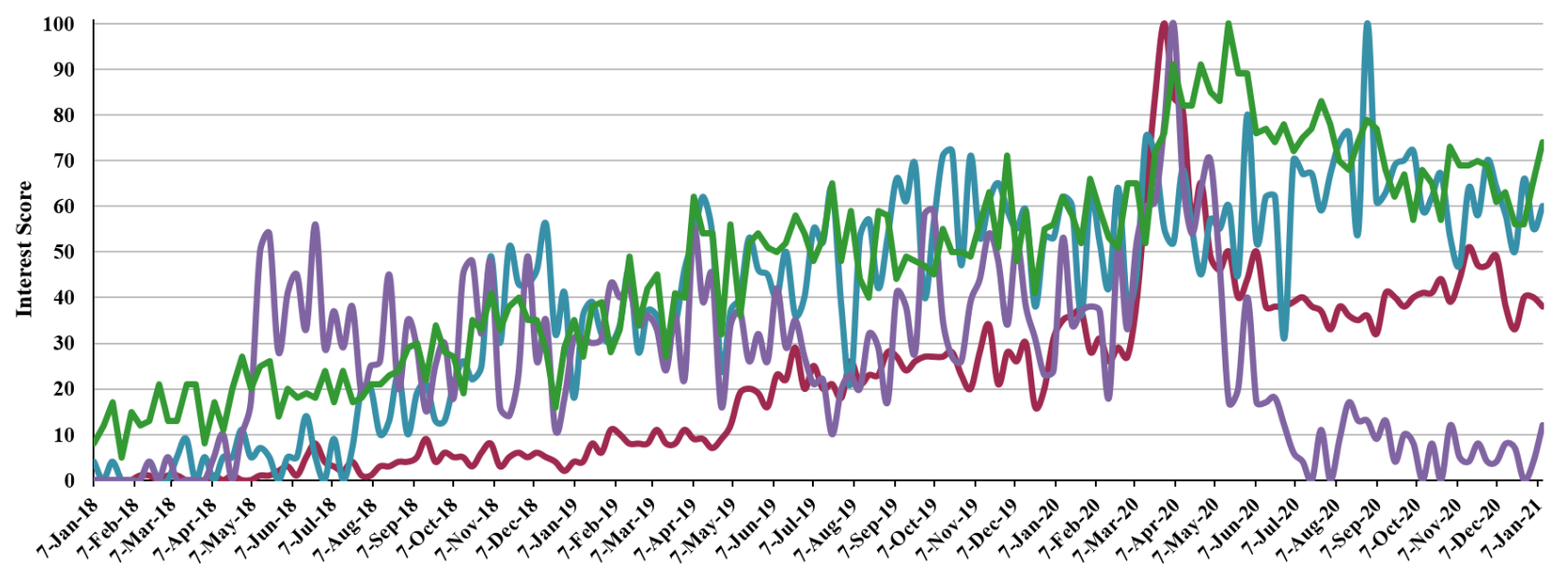

PICBE |

313

\begin{abstract}
Figure 6. The interest scores evolution of the following Google web researches:
"Glovo", "Takeaway", "Uber Eats" and "FoodPanda"

Source: Authors' visual representation of Google Inc.'s raw data, 2021, https://trends.google.com/trends/explore?date=today\%205-y\&geo=RO\&q=Glovo.
\end{abstract}

In March 2020, food ordering and home delivery companies were Google searched more than they had ever been since they had started their operations in Romania, with the exception of Food Panda, which has been active since 2013. Glovo peaked at an interest score of 100 on 22 March 2020, followed by Uber Eats on 5 April 2020. Food Panda reached maximum interest score later, on 17 May 2020, while Takeaway was the last to reach an interest score of 100 on 30 August 2020. Uber Eats decided to close its operations in Romania in June, 2020. Not only that, but the company also closed its operations in others countries like Czech Republic, Egypt, Honduras, Saudi Arabia, Ukraine, and Uruguay. According to Reuters (2020), this decision was adopted because the previously mentioned markets did not offer a clear route for Uber Eats to become number one or number two in the top of online food delivery operators, and that was the aim of Uber Eats. In such a competitive food service market, it is expected that tensions will continue to rise if the COVID-19 does not come to an end soon.

\title{
Conclusion
}

After almost one year since the COVID-19 pandemic was declared, major socio-economic and sanitary global havoc is caused by the pandemic at the beginning of 2021 . The effects on the agrifood chains and on the links involved in the chain are different based on the typology of the chain. In some cases (food delivery companies, for example) some advantages generated by the pandemic were observed during various stages of its evolution, while the links involved in the production and processing of raw agricultural materials were subject to additional tensions caused by a general feeling of food insecurity in the case of consumers.

In this paper, the rising tensions along the Romanian agri-food value chains were explored during different stages of the COVID-19 crisis in Romania. The HoReCa industry was brought in the spotlight of this study, and, more specifically, the food service component. The novelty factor of this paper resides in the fact insight was provided on the emergence of additional pressure on the links of the Romanian agri-food value chains during the COVID-19 crisis.

Based on Google Trends data, the interest for the HoReCa industry was studied. A boom in the interest score was observed in March (interest score of 82), followed by a decrease in April 
(interest score of 16) and by a small increase in May (interest score of 53 on May 3, 2020), with a peak on October 4, 2020 (interest score of 100), only to begin rising again in January 2021. Results confirm that the restrictions imposed by limiting the spread of the COVID-19 disease caused an increase of the intention for travelling, dining at restaurants and other similar leisure activities. Although the restrictions have changed during the COVID-19 pandemic evolution, the interest was kept alive for carrying out activities specific to travelling, dining, food tourism and others.

The agri-food value chain was positively impacted if approached through the lens of the links dealing with main food ordering and home delivery. At the beginning of the pandemic in March 2020, food ordering and home delivery companies were Google searched more than they had ever been since they had started their operations in Romania.

This research can be easily replicated to study if other countries were facing tensions rising along the agri-food value chains during the COVID-19 crisis. Not only that, but this research can also be extended by analyzing more relevant agri-food chain links within the framework of open-access data concerning interest trends.

\section{Funding}

This paper was co-financed by The Bucharest University of Economic Studies during the PhD program. The funder had no role in the design of the study; in the collection, analyses, or interpretation of data; in the writing of the manuscript, or in the decision to publish the results.

\section{References}

Andrei, J.V. and Drăgoi, M.C. (2020). A Brief Analysis of Tourism Economics in the EU - Is There a Massive Economic Potential of Change, TISC - Tourism International Scientific Conference Vrnjačka Banja, 5(1), 59-76.

Balaguer, J., \& Cantavella-Jorda, M. (2002). Tourism as a long-run economic growth factor: the Spanish case, Applied economics, 34(7), 877-884.

Batool, M., Ghulam, H., Hayat, M.A., Naeem, M.Z., Ejaz, A., Imran, Z.A., Spulbar, C., Birau, R. and Gorun, T.H. (2020). How COVID-19 has shaken the sharing economy? An analysis using Google trends data, Economic Research - Ekonomska Istraživanja, 1-13.

Berti, G., \& Mulligan, C. (2016). Competitiveness of Small Farms and Innovative Food Supply Chains: The Role of Food Hubs in Creating Sustainable Regional and Local Food Systems, Sustainability, 8(7), 616, https://doi.org/10.3390/su8070616.

Béné, C. (2020). Resilience of local food systems and links to food security - A review of some important concepts in the context of COVID-19 and other shocks, Food Security.

Bhangu, K.S., Sandhu, J. and Sapra, L. (2021). Time series analysis of COVID-19 cases, World Journal of Engineering, https://doi.org/10.1016/j.chaos.2020.109945.

Ziarul BURSA. (2021). Restaurantele din Capitală, la un pas de reluarea activităţii [online] https://www.bursa.ro/restaurantele-din-capitala-la-un-pas-de-reluarea-activitatii-442881 47, Accessed 24 Jan. 2021.

Butu, A., Brumă, I.S., Tanasă, L., Rodino, S., Dinu Vasiliu, C., Doboș, S. and Butu, M. (2020). The Impact of COVID-19 Crisis upon the Consumer Buying Behavior of Fresh Vegetables Directly from Local Producers. Case Study: The Quarantined Area of Suceava County, Romania, International Journal of Environmental Research and Public Health, 17(15), p. 5485, https://doi.org/10.3390/ijerph17155485.

Chang, H., \& Meyerhoefer, C. D. (2020). COVID-19 and the Demand for Online Food Shopping Services: Empirical Evidence from Taiwan, American Journal of Agricultural Economics. 
Choi, H. and Varial, H. (2012). Predicting the Present with Google Trends, Economic Record, 88, 2-9, https://doi.org/10.1111/j.1475-4932.2012.00809.x.

DIGI24. (2020). Ludovic Orban: De la 15 mai, se deschid hotelurile, dar nu și restaurantele. https://www.digi24.ro/stiri/economie/ludovic-orban-de-la-15-mai-se-deschid-hoteluriledar-nu-si-restaurantele-contributia-horeca-la-pib-e-limitata-1301919, Accessed Jan. 2021.

Dinu, M., Pătărlăgeanu, S.R., Constantin, M. and Tărăşilă, A. (2021). An Econometric Analysis of the Relationship Between Tourist Arrivals in Tourist Accommodation Structures in Romania and the Number of Overnight Stays, Business Revolution in a Digital Era, 271-285, https://doi.org/10.1007/978-3-030-59972-0_19.

Drăgoi, M.C., Andrei, J.V., Mieilă, M., Panait, M., Dobrotă, C.E., and Lădaru, R.G. (2018). Food safety and security in Romania: An econometric analysis in the context of national agricultural paradigm transformation, Amfiteatru Economic, 20(47), 134-150.

Forbes România. (2020). HoReCa: Se suspendă activitatea în semn de protest. [online] https://www.forbes.ro/horeca-se-suspenda-activitatea-in-semn-de-protest-179028, Accessed 24 Jan. 2021.

Gössling, S., Scott, D., \& Hall, C. M. (2020). Pandemics, tourism and global change: a rapid assessment of COVID-19, Journal of Sustainable Tourism, 29(1), 1-20.

Gómez, A.M.A. and Favorito, L.A. (2020). The Social, Economic and Sanitary Impact of COVID-19 Pandemic. International braz j urol, 46, 3-5.

Google Inc. (2021). FAQ about Google Trends data. [online] Available at: https://support. google.com/trends/answer/4365533, Accessed 22 Jan. 2021.

Government of Romania. (2020). Ordonanța de Urgență a Guvernului nr. 224 (Government Emergency Ordinance no. 224), [online] Available at: http://legislatie.just.ro/Public/Detalii Document/235872.

Hâncean, M.-G., Perc, M. and Lerner, J. (2020). Early spread of COVID-19 in Romania: imported cases from Italy and human-to-human transmission networks, Royal Society Open Science, 7(7), p. 200780, https://doi.org/10.1098/rsos.200780.

Ignat, R., and Constantin, M. (2020a). Multidimensional Facets of Entrepreneurial Resilience during the COVID-19 Crisis through the Lens of the Wealthiest Romanian Counties. Sustainability, 12(23), p. 10220, https://doi.org/10.3390/su122310220.

Ignat, R., and Constantin, M. (2020b). Short-Term Effects of COVID-19 Pandemic on Agri-Food Value Chains in Romania. In: Proceedings of the International Conference on Economics and Social Sciences, [online] Bucharest, Romania: Sciendo, 578-588, Available at: https://doi.org/10.2478/9788395815072-058.

Istudor, N., Ion, R.A., Petrescu, I.E. and Hrebenciuc, A. (2018). Agriculture and the Twofold Relationship between Food Security and Climate Change. Evidence from Romania, Amfiteatru Economic, 21(51), 285-293.

Jun, S.-P., Yoo, H.S., and Choi, S. (2018). Ten years of research change using Google Trends: From the perspective of big data utilizations and applications, Technological Forecasting and Social Change, 130, 69-87.

Konishi, Y. (2019). Global Value Chain in Services: The Case of Tourism in Japan, Journal of Southeast Asian Economies, 36(2), 183-203, https://doi.org/10.2307/26798832.

Mikulic, D., Decek, D., \& Hrustek, N. Z. (2017). Overall Contribution of the Foreign Tourist Demand on Croatian Economy. Tourism in South East Europe. The $4^{\text {th }}$ International Scientific Conference on ToSEE - Tourism in Southern and Eastern Europe, Opatija, Croatia, May 04-06, 2017. 
Nikolopoulos, K., Punia, S., Schäfers, A., Tsinopoulos, C., and Vasilakis, C. (2021). Forecasting and planning during a pandemic: COVID-19 growth rates, supply chain disruptions, and governmental decisions, European Journal of Operational Research, 290(1), 99-115.

Raj, M., Sundararajan, A., \& You, C. (2020). COVID-19 and Digital Resilience: Evidence from Uber Eats, NYU Stern School of Business Research Paper Series.

Pătărlăgeanu, S.R., Constantin, M., and Dinu, M. (2020). Considerations Regarding The Horeca Industry In Bihor County. An Econometric Approach, Oradea Journal of Business and Economics, 5(1), 7-17, https://doi.org/10.47535/1991ojbe084.

Reuters (2020). Uber closes Eats operations in eight smaller markets. [online] https://www.reuters. com/article/us-uber-eats-markets/uber-closes-eats-operations-in-eight-smaller-marketsidUSKBN22G15N, Accessed 25 Jan. 2021.

RFI România (2020). Angajaţii din industria HoReCa protestează în Piaţa Victoriei, [online] https://www.rfi.ro/social-125855-angajatii-din-industria-horeca-protesteaza-piata-victoriei, Accessed 24 Jan. 2021.

Polkowska, D. (2020). Platform work during the COVID-19 pandemic: a case study of Glovo couriers in Poland. European Societies, 1-11.

Schubert, S.F., \& Schamel, G. (2020). Sustainable tourism development: A dynamic model incorporating resident spillovers, Tourism Economics, 135481662093455, https://doi.org/ $10.1177 / 1354816620934552$.

Shahbaz, M., Bilal, M., Moiz, A., Zubair, S. and Iqbal, H.M.N. (2020). Food Safety and COVID19: Precautionary Measures to Limit the Spread of Coronavirus at Food Service and Retail Sector, Journal of Pure and Applied Microbiology, 14, 749-456.

Tang, C.H.H., \& Jang, S.S. (2009). The tourism-economy causality in the United States: A subindustry level examination, Tourism Management, 30(4), 553-558.

The National Institute for Statistics - Romania (2020). TEMPO Online Database, [online] Available at: http://statistici.insse.ro:8077/tempo-online/, Accessed 22 Jan. 2021.

Vosen, S., and Schmidt, T. (2011). Forecasting private consumption: survey-based indicators vs. Google trends, Journal of Forecasting, 30(6), 565-578.

Wang, X., Yang, L., Zhang, H., Yang, Z., and Liu, C. (2021). Forecasting confirmed cases of the COVID-19 pandemic with a migration-based epidemiological model, Statistics and Its Interface, 14(1), 59-71.

World Health Organization (2020). WHO Director-General's Opening Remarks at the Media Briefing on COVID-19 - 11 March 2020, [online] Available at: https://www.who.int/ director-general/speeches/detail/who-director-general-s-opening-remarks-at-the-mediabriefing-on-covid-19---11-march-2020. 